\title{
SUSCEPTIBILITY OF CERTAIN SUGAR BEET VARIATEIES TO INFESTATION WITH Pegomyia mixta VILL. AND Cassida vittata VILL. IN RELATION TO THE YEILD CROP AT KAFR EL-SHEIKH GOVERNORATE \\ EI-Khouly M. I. \\ Plant- Protection Research Institute, Agricultural Research Center, Dokki, Giza, Egypt
}

\begin{abstract}
The population density of the beet fly, Pegomyia mixta Vill. attacking for seven sugar beet varieties during the two successive seasons (2004/2005 and 20052006). It was found $P$. mixta has between one to three peaks on Lola, Carola, Kws 1436 , Hend ${ }_{9422}, 3 \mathrm{~S}_{40}$, Anema and Top varieties. Also, the range same trend was observed in the second season (2005-2006). Infestation rates of $P$. mixta. were studied on seven varieties (Lola, Carola, Kws ${ }_{1436}$, Hend ${ }_{9422}, 3 S_{40}$, Anema and Top). Kws 1436 variety was the most susceptible than Top variety to $P$. mixta infestation. The moderate susceptible variety was Hend9422 during (2004-2005 \& 2005-2006). The population density of the tortoise beetle, Cassida vittata Vill. attacking for seven sugar beet varieties during the two successive seasons (2004/2005 and 2005-2006). It was found C. vittata has between one to two peaks on Lola, Carola, Kws 1436 , Hend9422, 3S 40 , Anema and Top varieties. Also, the range same trend was observed in the second season (2005-2006). Infestation rates of $P$. mixta were studied on seven varieties (Lola, Carola, Kws 1436 , Hend9422, $3 S_{40}$, Anema and Top). Anema variety was more susceptible than $3 S_{40}$ variety to $C$. vittata infestation. The moderate susceptible variety was Hend9422 during 2004-2005 sesaon. While during 2005-2006 season, found Kws 1436 variety was more susceptible than Top variety to $C$. vittata infestation. The moderate susceptible variety was Lola. The correlation between the infestation rate, root yield and sugar percentages of $P$. mixta and $C$. vittata on some varieties of sugar beet also, studied. $3 S_{40}$ and Top varieties had the maximum yield Ton/fed. In addition, the sugar percentage of the two varieties reached the maximum. On the other hand, Anema variety had the minimum yield (Ton/fed.). The other varieties the yield ranged between (Lola to Carola), also, the sugar percentage ranged between (Lola-Kws1436). In conclusion, $3 \mathrm{~S}_{40}$ and Top varieties gave the highest root yield and sugar production that we concluded with the lowest infestation rate by the two insect pests, $P$. mixta (larvae) and $C$. vittata (larvae and adults) compared with the other varieties.
\end{abstract}

\section{INTRODUCTION}

The beet fly, Pegomyia mixta Vill. (Anthomyiidae : Diptera) and the tortoise beetle, Cassida vittata Vill. (Chrysomelidae : Coleoptera) are the most two economic important insect pests infesting sugar beet in Egypt (Guirguis, 1985, Salouma 1989, Awadalla et al., 1991 and Youssef 1994). Iskander (1982) observed that $P$. mixta was one of the most serious pest threatening sugar beet plantations attacking the plant in all stages of its growth, particularly full-grown mature leaves. The larvae penetrate into the leaves causing the appearance of wide blotch and shaped areas on them and finally dry up. Awadalla et al. (2001) found that, the maximum abundance of the egg stage was in mid-March and early-May. The larval populations have 


\section{EI-Khouly M. I.}

three successive peaks occurred at mid-January, late-March, and early-May. Abou-Said Ahmed (1987) stated that larvae affected the quantity of root yield by this pest, while sugar percentage was not significantly affected. Ebieda (1998) showed that the injury levels of the main properties (quantity and quality) of roots, leaves, sugar grow yield, root: leaves ratio and \%root/gross yield were affected by the infestation by $P$. mixta. El-Khouly (1998) illustrated considerable decrement in root weight, root sugar content, weight of foliage and number of plant leaves as infestation levels of both larva or adult increased. Leaf number increased by the increase of infestation rates of $C$. vittata. At infestation levels of 25,50 and 100 larvae/adults/plat. At the same trend sugar yield crop degraded in quality and quantity. Mousa (2005) indicated that Top variety was less sensitive for P. mixta, while Kwsa421 received moderate infestation for the same insect. He recorded Top variety received the lowest number of $C$. vittata.

Thus, the present study was carried out to clarify the correlation between the infestation levels of both insects Pegomyia mixta and Cassida vittata Vill. On the produced root and sugar yields of seven sugar beet varieties.

\section{MATERIALS AND METHODS}

\section{Experimentation:}

The present study was carried out in Delta Sugar Company Farm in El-Hamoul District, Kafr El-Sheik Governorate, during the two seasons $2004 / 2005$ and 2005/2006.

The experimental area (about $1 / 2$ Feddan), the mid-October as normal planting date was divided into 28 plots $\left(6 \times 7=42 \mathrm{~m}^{2}, 1 / 100\right.$ of fed.). Every sugar beet variety was cultivated in an area $\left(168 \mathrm{~m}^{2}\right)$. An area of each sugar beet variety divided to 4 replicates in a complete randomized block design, with a space of $1 \mathrm{~m}$ wide belt between plots. An unplanted belt $(2 \mathrm{~m}$ wide) was left around the experimental area. The seven sugar beet varieties Lola, Carola, Kws 1436 , Hend9422, 3S40, Anema and Top were cultivated randomly in four plots.

\section{Agricultural practices and sampling:}

Al normal agricultural practices were followed with no insecticides applications.

Starting from early November, a sample of 10 plants/plot was picked up randomly every 10 days intervals continued until the end of May at the harvest time. Recorded the counts of $P$. mixta and $C$. vittata. Leaves were examined for the infestation to both insects, and the counts of them were taken. At harvest times, a hundred sugar beet roots was randomly taken from the middle ridge along $2 \mathrm{~m}$ for each plot. The roots were brushed and transferred immediately to laboratory of Delta sugar company immediately where cut off from the roots and weighed. Also, the root sucrose percentage was determined in the cleaned roots by using Saccharometer on a lead basis according to the procedure of Le Docte (1927). 
3. Determination of technological characteristics:

Were calculated by the following equations of Delta sugar company:

a. Sugar recovery (SR) (white sugar):

SR = Pol-0.29-0.343 $(\mathrm{K}+\mathrm{Na})-\alpha \mathrm{NX} 0.94$

Where : Plo $=$ Sucrose $\%$

b. Percentages of Sugar losses in wastes (C):

$\mathrm{D}=(\mathrm{K}+\mathrm{Na}, 34++\alpha \mathrm{NX} 0.094-0.129)$

c. Juice purity:

Obtained according to Sapronov et al. (1979).

Purity $=$ Sucrose $\%$ X 100 (soluble solid $\%$ )

d. Estimation of $P$. mixta and $C$. vittata damage:

The damage caused by $P$. mixta and $C$. vittata was estimated by the following equation according to (Delta Sugar Company):

Sugar yield $($ Ton/fed. $)=$ root yield sucrose $X$ prity $/ 100$.

The microcomputer program ANOVA was used for statistical analysis and the Duncan's multiple range tests was used for separating means.

\section{RESULTS AND DISCUSSION}

1. Population density of the beet fly, Pegomyia mixta Vill. for seven sugar beet varieties during the two successive seasons (2004/2005 and 2005-2006):

1.1. During (2004/2005) sesaon:

Data in Fig. (1) shows that the population density of the beet fly, $P$. mixta attacking seven sugar beet varieties during the first season (2004/2005).

It was found $P$. mixta has activity peak during $13^{\text {th }}$ February with mean number 99 individuals, then the population where decreased and increased again to make activity broad ranged from 14 1 th March, 2005 (92 individuals $/ 40$ plants) till $3^{\text {rd }}$ April, 2005 (91 individuals) on Lola Varity. On Carola variety, it was found $P$. mixta has two activity peaks during $13^{\text {th }}$ February and $14^{\text {th }}$ March 2005 with mean number 101 and 109 individuals /40 plants, respectively. While, on Kws 1436 the population density of $P$. mixta has three activity peaks during $4^{\text {th }}$ January, $13^{\text {th }}$ February and $14^{\text {th }}$ March 2005 with mean number 59, 112 and 127 individuals, respectively. On the other hand, on Hend9422 it was found $P$. mixta has activity peak during $13^{\text {th }}$ February with mean number 98 individuals, then the population where decreased and increased again to make activity broad ranged from $14^{\text {th }}$ March (100 individuals) till $13^{\text {th }}$ April, 2005 (99 individuals). On 3S 40 variety, found $P$. mixta has two activity peaks during $13^{\text {th }}$ February and $14^{\text {th }}$ March 2005 with mean number 103 and 125 individuals, respectively. On Anema variety has one activity peak on $10^{\text {th }}$ February with mean number 115 individuals. On Top, variety has broad ranged between $3^{\text {rd }}$ February until $5^{\text {th }}$ March with mean number 82 and 82 individuals, respectively. 
EI-Khouly M. I.

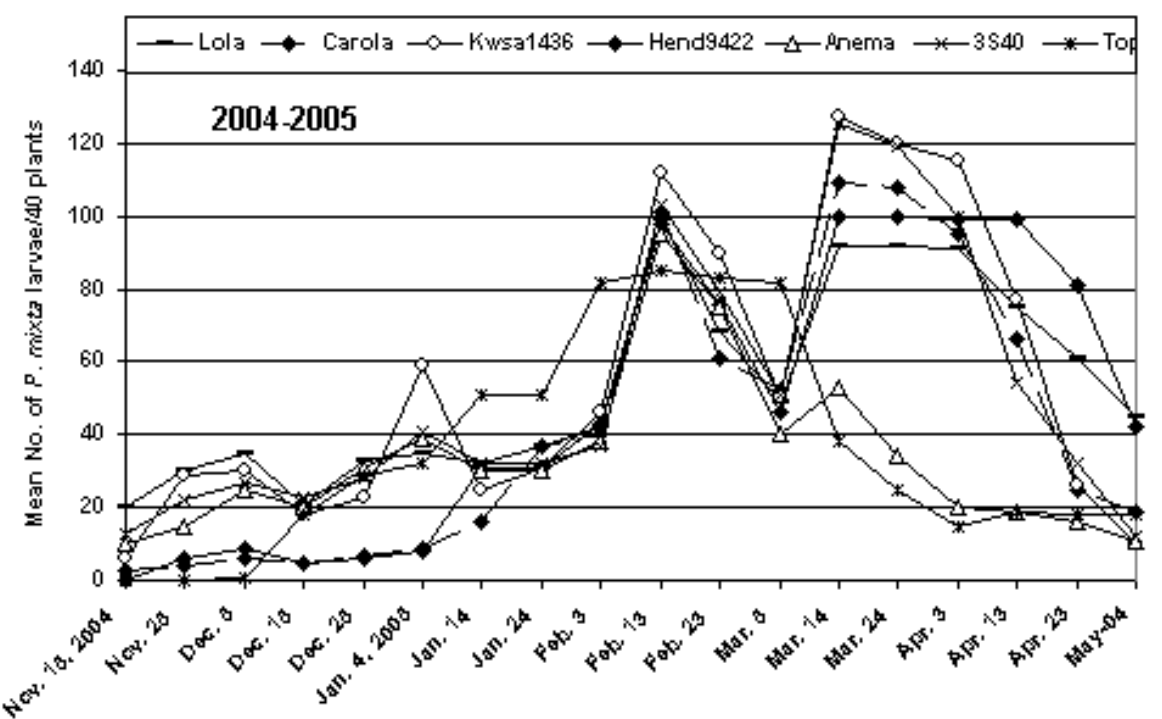

Fig. (1): Mean number of the beet fly, $P$. mixta (larvae) for seven sugar beet varieties during the frist season 2004/05.

1.2. During (2005/06) sesaon:

Data in Fig. (2) shows that the population density of the beet fly, $P$. mixta attacking for seven sugar beet varieties during the fist season (2005/2006).

It was found $P$. mixta has two activity peaks during $10^{\text {th }}$ February and $24^{\text {th }}$ March with mean number 108 and 111 individuals, respectively on Lola Varity. On Carola variety, it was found $P$. mixta has two activity peaks during $10^{\text {th }}$ February and $24^{\text {th }}$ March 2005 with mean number 93 and 108 individuals, respectively. While, on Kws 1436 the population density of $P$. mixta has two activity peaks during 10 April, and 24 ${ }^{\text {th }}$ March 2005 with mean number 111 and 150 individuals, respectively. On the other hand, on Hend9422 variety, found $P$. mixta has activity peak during $10^{\text {th }}$ February with mean number 102 individuals. On $3 S_{40}$ variety, found $P$. mixta has two activity peaks during $10^{\text {th }}$ February and $24^{\text {th }}$ March 2005 with mean number 119 and 130 individuals, respectively. On Anema variety, has one activity peak on $10^{\text {th }}$ February with mean number 115 individuals. On Top, variety has two activity peaks during $10^{\text {th }}$ February and $24^{\text {th }}$ March with mean number 105 and 79 individuals, respectively. 
J. Agric. Sci. Mansoura Univ., 32 (6), June, 2007

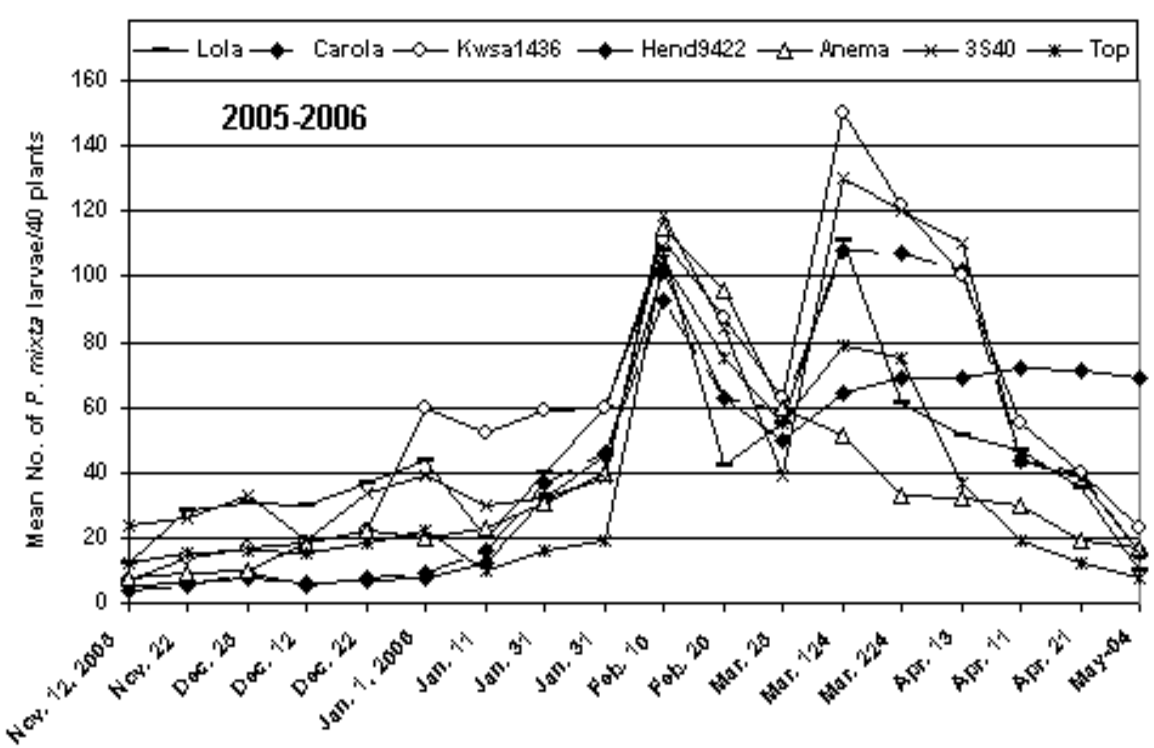

Fig. (2): Mean number of the beet fly, $P$. mixta (larvae) for seven sugar beet varieties during the second season 2005/06.

\section{Infestation rates of $P$. mixta on some varieties of sugar beet:}

\subsection{During 2004-2005 season:}

The total number of larvae of $P$. mixta were 957, 763, 1004, 866, 599, 924 and 634/18 inspections of seven varieties, Lola, Carola, Kws 1436, Hend $9422,3 \mathrm{~S}_{40}$, Anema and Top, while the mean number of these varieties were 136.7, 109.0, 143.43, 123.71, 85.57, 132.00 and 90.57/40 plants, respectively.

As shown in Table (1) Kws 1436 variety was more susceptible (143.43) than Top variety (90.57) to $P$. mixta infestation. The moderate susceptible variety was Hend 9422 (123.71).

Statistical analysis of the data, showed highly significant differences between seven sugar beet varieties as the infestation with $P$. mixta, $(F=$ 714.44 on $\mathrm{P}<0.05$ ) and $\mathrm{LSD}=2.57$.

\subsection{During 2005-2006 season:}

The total number of larvae of $P$. mixta were $852,770,1060,758$, 634, 974 and 608/18 inspections of seven varieties, Lola, Carola, Kws 1436 , Hend $9422,3 \mathrm{~S}_{40}$, Anema and Top, while the mean number of these varieties were $121.71,110.00,151.43,108.29,90.57,139.14$ and 86.86/40 plants, respectively.

As shown in Table (2) Kws 1436 variety was more susceptible (151.433) than Top variety (90.57) to $P$. mixta infestation. The moderate susceptible variety was Hend 9422 (108.29).

Statistical analysis of the data, showed highly significant differences between seven sugar beet varieties as the infestation with $P$. mixta, $(F=$ 1428.69 on $\mathrm{P}<0.05)$ and $\mathrm{LSD}=1.91$. 
EI-Khouly M. I.

Table (1): $\quad$ Mean numbers of the beet fly, $P$. mixta Larvae for seven sugar beet varieties during 2004/2005 season.

\begin{tabular}{|c|c|c|c|c|c|c|c|}
\hline \multirow{2}{*}{$\begin{array}{l}\text { Inspection } \\
\text { date }\end{array}$} & \multicolumn{7}{|c|}{ Varieties } \\
\hline & Lola & Carola & KwS 1436 & Hend 9422 & $3 S_{40}$ & Anema & Top \\
\hline Nov. 2004 & 50 & 7 & 45 & 6 & 25 & 35 & 0 \\
\hline Dec. & 89 & 18 & 71 & 20 & 76 & 78 & 48 \\
\hline Jan. 2005 & 104 & 62 & 115 & 56 & 97 & 99 & 121 \\
\hline Feb. & 209 & 202 & 248 & 217 & 208 & 219 & 240 \\
\hline March & 233 & 269 & 297 & 246 & 127 & 295 & 155 \\
\hline April & 227 & 186 & 218 & 279 & 55 & 186 & 52 \\
\hline May & 45 & 19 & 10 & 42 & 11 & 12 & 18 \\
\hline Total & 957 & 763 & 1004 & 866 & 599 & 924 & 634 \\
\hline Mean & $136.7^{a}$ & $109.0^{\mathrm{e}}$ & $143.43^{\mathrm{a}}$ & $123.71^{d}$ & $85.58^{\mathrm{g}}$ & $132.00^{c}$ & $90.57^{f}$ \\
\hline $\mathbf{F}$ & \multicolumn{7}{|c|}{$\begin{array}{c}* \star * \\
714.44\end{array}$} \\
\hline LSD & \multicolumn{7}{|c|}{9.57} \\
\hline
\end{tabular}

Table (2): Mean numbers of the beet fly, Pegomyia mixta larvae for seven sugar beet varieties during 2005/2006 seasons.

\begin{tabular}{|c|c|c|c|c|c|c|c|}
\hline \multirow{2}{*}{$\begin{array}{l}\text { Inspection } \\
\text { date }\end{array}$} & \multicolumn{7}{|c|}{ Varieties } \\
\hline & Lola & Carola & $\mathrm{KWS}_{1436}$ & Hend $_{9422}$ & $3 S_{40}$ & Anema & Top \\
\hline Nov. 2005 & 40 & 9 & 21 & 11 & 17 & 50 & 27 \\
\hline Dec. & 98 & 22 & 57 & 21 & 50 & 86 & 49 \\
\hline Jan. 2006 & 164 & 108 & 231 & 97 & 114 & 139 & 67 \\
\hline Feb. & 180 & 156 & 198 & 165 & 211 & 203 & 180 \\
\hline March & 227 & 274 & 335 & 183 & 144 & 289 & 209 \\
\hline April & 133 & 186 & 195 & 212 & 81 & 192 & 68 \\
\hline May & 10 & 15 & 23 & 69 & 17 & 15 & 8 \\
\hline Total & 852 & 770 & 1060 & 758 & 634 & 974 & 608 \\
\hline Mean & $121.71^{\mathrm{c}}$ & $110.00^{d}$ & $151.43^{a}$ & $108.29^{d}$ & $90.57^{\mathrm{e}}$ & $139.14^{b}$ & $86.86^{f}$ \\
\hline \multirow{2}{*}{$\mathbf{F}$} & \multirow{2}{*}{\multicolumn{7}{|c|}{$\begin{array}{c}\star \star \star \star \\
1428.69\end{array}$}} \\
\hline & & & & & & & \\
\hline LSD & \multicolumn{7}{|c|}{1.91} \\
\hline
\end{tabular}

3. Population density of Cassida vittata (larvae \& adults) for seven sugar beet varieties during the two successive seasons (2004/2005 and 2005-2006):

3.1. During (2004/2005) sesaon:

Data in Fig. (3) shows that the population density of the tortoise beetle, $C$. vittata attacking for seven sugar beet varieties during the first season (2004/2005).

It was found $C$. vittata has two activity peak during $14^{\text {th }}$ March and $23^{\text {rd }}$ April with mean number 95 and 150 individuals on Lola Varity. On Carola variety, it was found $C$. vittata has two activity peaks during $14^{\text {th }}$ May and $13^{\text {th }}$ April 2005 with mean number 85 and 130 individuals, respectively. In addition, on Kws 1436 the population density of $C$. vittata has two activity peaks 
during $14^{\text {th }}$ March and 13 April with mean number 97 and 165 individuals, respectively. On the other hand, on Hend 9422 it was found $C$. vittata has two activity peaks during 14 March and $13^{\text {th }}$ April with mean number 89 andf 123 individuals, respectively. On $3 S_{40}$ variety, found $C$. vittata has two activity peaks during 14 March and $13^{\text {th }}$ April 2005 with mean number 97 and 165 individuals, respectively. On Anema variety, has two activity peaks during 14 March and $13^{\text {th }}$ April 2005 with mean number 150 and 202 individuals, respectively. On Top variety, found two activity peaks during 14 March and $13^{\text {th }}$ April 2005 with mean number 39 and 45 individuals, respectively.

\subsection{During (2005/2006) sesaon:}

Data in Fig. (4) shows that the population density of $C$. vittata Vill. attacking for seven sugar beet varieties during the fist season (2005/2006).

It was found $C$. vittata has one activity peak during 12 March with mean number 155 individuals, respectively on Lola Varity. On Carola variety, found $C$. vittata has one activity peak during $2^{\text {nd }}$ March with mean number 83 individuals. While, on Kws 1436 the population density of $C$. vittata has one activity peak during $12^{\text {th }}$ March with mean number 103 individuals. On the other hand, on Hend9422 variety, found $C$. vittata has activity peak during 12 March with mean number 141 individuals. On $3 S_{40}$ variety, found $C$. vittata has activity peak during 12 March with mean number 37 individuals. On Anema variety, has one activity peak on $12^{\text {th }}$ March with mean number 148 individuals. On Top, variety has two activity peaks during 12 March and $11^{\text {th }}$ April with mean number 39 and 45 individuals, respectively.

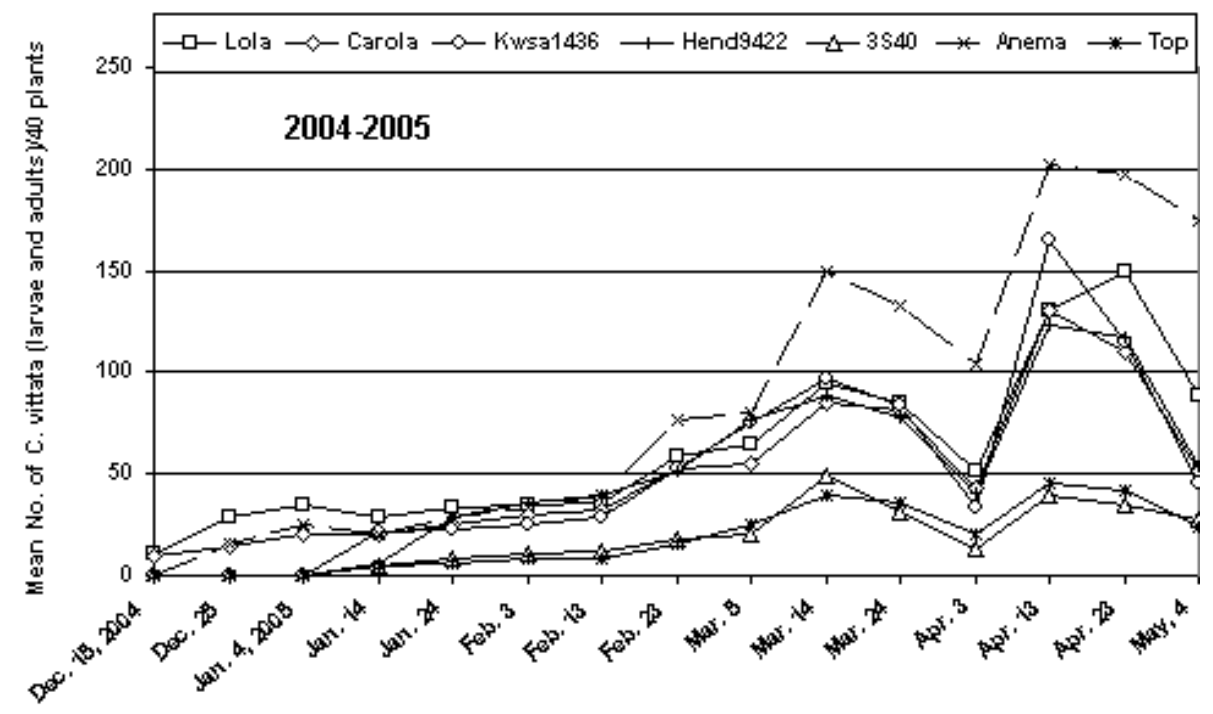

Fig. (3): Mean number of the tortoise beetle, C. vittata (larvae \& adults) for seven sugar beet varieties during the first seasons 2004/05 . 


\section{El-Khouly M. I.}

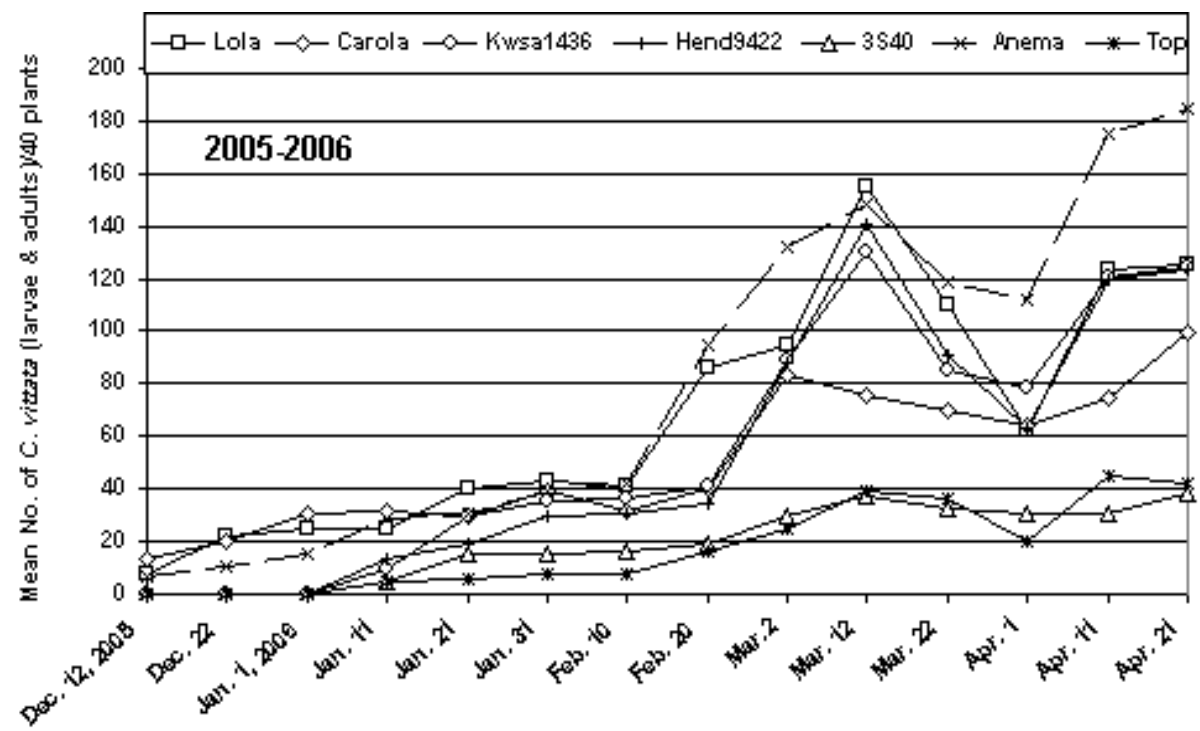

Fig. (4): Mean number of the tortoise beetle, C. vittata (larvae \& adults) for seven sugar beet varieties during the second seasons 2005/06.

\section{Infestation rates of the tortoise beetle, Cassida vittata on some varieties of sugar beet: \\ 4.1. During 2004-2005 season:}

The total number of larvae of $C$. vittata were $933,758,765,740,268$, 1279 and 274/18 inspections of seven varieties, Lola, Carola, Kws 1436 , Hend ${ }_{9422}, 3 \mathrm{~S}_{40}$, Anema and Top, while the mean number of these varieties were $155.5,126.33,127.5,123.33,44.67,213.17$ and $45.67 / 40$ plants, respectively.

As shown in Table (3) Anema variety was more susceptible (213.17) than $3 S_{40}$ variety (44.67) to $C$. vittata infestation. The moderate susceptible variety was Hend9422 (123.33).

Statistical analysis of the data, showed highly significant differences between seven sugar beet varieties as the infestation with $C$. vittata, $(F=$ 1459.92 on $\mathrm{P}<0.05)$ and $\mathrm{LSD}=4.72$.

4.2. During 2005-2006 season:

The total number of larvae of $C$. vittata were 1100, 820, 929, 928, 311,1339 and 274/18 inspections of seven varieties, Lola, Carola, Kws 1436 , Hend ${ }_{9422}, 3 \mathrm{~S}_{40}$, Anema and Top, while the mean number of these varieties were 103.33, 136.67, 154.83, 154.67, 51.83, 223.17 and 45.67/40 plants, respectively.

As shown in Table (4) Kws 1436 variety was more susceptible (154.83) than Top variety (45.67) to $C$. vittata infestation. The moderate susceptible variety was Lola (103.33). 
Statistical analysis of the data, showed highly significant differences between seven sugar beet varieties as the infestation with $P$. mixta, $(\mathrm{F}=$ 9032.75 on $\mathrm{P}<0.05$ ) and LSD $=2.003$.

The obtained results are agreement with those obtained by Mousa (2005), who proved that Top variety is lowest, reaccepted with infestation by C. vittata.

Table (3): Mean number of the tortoise beetle, C. vittata (larvae \& adults) for seven sugar beet varieties during 2004/2005 season.

\begin{tabular}{|c|c|c|c|c|c|c|c|}
\hline \multirow{2}{*}{$\begin{array}{l}\text { Inspection } \\
\text { date }\end{array}$} & \multicolumn{7}{|c|}{ Varieties } \\
\hline & Lola & Carola & $\mathrm{KwS}_{1436}$ & Hend ${ }_{9422}$ & $3 S_{40}$ & Anema & Top \\
\hline Dec. 2004 & 40 & 23 & 0 & 0 & 0 & 16 & 0 \\
\hline Jan. 2005 & 97 & 65 & 44 & 35 & 13 & 74 & 11 \\
\hline Feb. & 130 & 115 & 107 & 126 & 41 & 148 & 32 \\
\hline March & 245 & 221 & 256 & 244 & 100 & 363 & 100 \\
\hline April & 332 & 283 & 313 & 281 & 87 & 503 & 107 \\
\hline May & 89 & 51 & 45 & 54 & 27 & 175 & 24 \\
\hline Total & 933 & 758 & 765 & 740 & 268 & 1279 & 274 \\
\hline Mean & $155.5^{b}$ & $126.33^{c}$ & $127.5^{\mathrm{c}}$ & $123.33^{c}$ & $44.67^{e}$ & $213.17^{a}$ & $45.67^{d}$ \\
\hline $\mathbf{F}$ & \multicolumn{7}{|c|}{$\begin{array}{c}* * \star \\
1459.92\end{array}$} \\
\hline LSD & \multicolumn{7}{|c|}{4.72} \\
\hline
\end{tabular}

Table (4): Mean number of the tortoise beetle, C. vittata (larvae \& adults) for seven sugar beet varieties during 2005/2006 season.

\begin{tabular}{|c|c|c|c|c|c|c|c|}
\hline \multirow{2}{*}{$\begin{array}{c}\text { Inspection } \\
\text { date }\end{array}$} & \multicolumn{7}{|c|}{ Varieties } \\
\hline & Lola & Carola & KwS $_{1436}$ & Hend $_{9422}$ & $3 S_{40}$ & Anema & Top \\
\hline Dec. 2005 & 30 & 33 & 0 & 0 & 0 & 18 & 0 \\
\hline Jan. 2006 & 133 & 132 & 75 & 62 & 35 & 114 & 19 \\
\hline Feb. & 127 & 72 & 77 & 65 & 35 & 137 & 24 \\
\hline March & 360 & 229 & 304 & 320 & 100 & 399 & 100 \\
\hline April & 310 & 239 & 323 & 306 & 100 & 472 & 107 \\
\hline May & 140 & 115 & 150 & 175 & 41 & 199 & 24 \\
\hline Total & 1100 & 820 & 929 & 928 & 311 & 1339 & 274 \\
\hline Mean & $103.33^{d}$ & $136.67^{c}$ & $154.83^{b}$ & $154.67^{b}$ & $51.83^{e}$ & $223.17^{a}$ & $45.67^{f}$ \\
\hline \multirow{2}{*}{$\mathbf{F}$} & \multicolumn{7}{|c|}{ (1) } \\
\hline & \multicolumn{7}{|c|}{$\frac{9032.75}{2.003}$} \\
\hline
\end{tabular}

2. The relationship between the infestation rate, root yield and sugar percentages of Pegomyia mixta and Cassida vittata on some varieties of sugar beet:

The relation between the infestation rates of $P$. mixta (larvae) and $C$. vittata (larvae and adults) and root yield of some varieties of sugar beet and their percentages were studies. 


\section{EI-Khouly M. I.}

Data in Table (5) showed that $3 S_{40}$ and Top varieties had the maximum yield $(20.5 \& 19.5)$ Ton/fed. with rate in infestation by the two insect pests, P. mixta and C. vittata, (113.05 \&58.0) and (103.6 \& 66.7), respectively, also, the sugar percentage of the two varieties reached 19.8 and 19.4, respectively.

On the other hand, the data indicated that Anema variety had the minimum yield (15.7 Ton/fed.) with rate in infestation by the two insect pests, P. mixta and C. vittata, (158.65 \& 295.4), respectively, also, the sugar percentage of the Anema variety reached 17.7.(Table 5).

The other varieties the yield ranged between (Lola 18.9 to Carola 20.1 Ton/fed.), respectively, also, the sugar percentage ranged between (Lola 17.8- Kws $\mathbf{w}_{1436}$ 19.3).

Statistical analysis of the data, showed highly significant differences between the infestation with $P$. mixta and $C$. vittata on seven sugar beet varieties and weight $($ Ton/fed.) $(F=8.37$ on $P<0.05)$ and $L S D=1.69$ and also give significant differences between the infestation with $P$. mixta and $C$. vittata on seven sugar beet varieties and \% of sucrose $(F=3.635$ on $P<$ $0.05)$ and LSD $=1.29$.

High quality and quantity of sugar beet crop are obtained with reduce pests attack.

In Egypt Ali (1988), pointed out that the number of pests of which attack sugar beet plants differs according to the crop rotation.

Table (5): Mean weight and \% of sucrose for seven sugar beet varieties combined as infestation with $P$. mixta and $C$. vittata from 2 seasons (2004/2005 and 2005/2006).

\begin{tabular}{|c|c|c|}
\hline \multirow{2}{*}{ Variety } & \multicolumn{2}{|c|}{ Mean } \\
\hline & Ton/fed. & Sucrose\% \\
\hline Lola & $18.9^{a}$ & $17.8^{\mathrm{c}}$ \\
\hline Carola & $20.1^{a}$ & $18.4^{\mathrm{ab}}$ \\
\hline $\mathrm{KWS}_{1436}$ & $19.6^{a}$ & $19.3^{a}$ \\
\hline Hend $_{9422}$ & $19.9^{a}$ & $18.8^{\mathrm{ab}}$ \\
\hline Anema & $20.5^{a}$ & $19.8^{a}$ \\
\hline $3 S_{40}$ & $15.7^{b}$ & $17.7^{c}$ \\
\hline Top & $19.5^{a}$ & $19.4^{a}$ \\
\hline & $\star \star \star$ & * \\
\hline $\mathbf{F}$ & 8.37 & 3.635 \\
\hline LSD & 1.69 & 1.29 \\
\hline
\end{tabular}

In general, it was observed that when the infestation rates increased the sugar percentage decreased. The maximum sugar percentages were attained by all varieties after planting on the recommended date.

In conclusion, $3 \mathrm{~S}_{40}$ and Top varieties gave the highest root yield and sugar production that we concluded with the lowest infestation rate by the two insect pests, P. mixta (larvae) and C. vittata (larvae and adults) compared with the other varieties.

The effects of $P$. mixta (larvae) and $C$. vittata on root yields and sugar percentages were observed by several studies such as, Abou-Said Ahmed (1987), El-Khouly (1992 \& 1998), Ebieda (1998). 


\section{REFERENCES}

Abo-Aiana, R. A. D. (1991): Studies on pests of sugar beet in Kafr El-Sheikh. Ph. D. Thesis, Fac. Agric. Tanta Univ.

Abou-Said Ahmed, A. M. B. (1987): Studies on the insects of sugar beet in Kafr El-Sheikh Governorate, Egypt. Ph. D. Thesis, Fac. Agric. Tanta Univ.

Aly, F. A. C. (1988): Population density of the beet fly, Pegomyia mixta Vill. On sugar beet and chard weed, Beta vulgaris as as alternative host. J. Agric. Sci., Mansoura Univ., 19 (1): 201-205.

Awadalla, S. S.; Ragab, M. E. and Fathy, H. M. (1991): Interaction between injurious and predatory insects inhabiting sugar beet plants in relation to varieties and planting dates. J. Biol. P. Cont., 1(2): 25-32.

Awadalla, S. S.; Shanab, L. M.; Fathy, H. M. and Zawrah, M. E. (2001): Ecological studies on the sugar beet fly, Pegomya mixta Vill. and its internal larval parsitoid, Opius nitidulator (Nees) in Mansoura District. Assuit Univ. Proceeding of the Conf. October, 28-29, 2001.

Ebieda, A. M. M. (1998): Studies on sugar beet pests. VI. Effect of beet fly, Pegomyia mixta Vill. on sugar beet with special reference to the determination of its injury levels and economic threshold. Egypt, J. Agric. Res., 76 (2): 681-694.

El-Khouly, M. I. (1992): Biological studies on the tortoise beetle, Cassida vittata Vill. attacking sugar beet. M. Sc. Thesis, Fac. Agric. Al-Azhar Univ.

El-Khouly, M. I. (1998): Ecological studies and control of the tortoise beetle, Cassida vittata Vill. in sugar beet ecosystem. Ph. D. Thesis, Fac. Agric. Al-Azhar Univ.

El-Saeady, A. A. and Shabaan, A. I. (1988): Seasonal abundance of Pegomyia mixta Vill. (Diptera : Anthomyiidae) on sugar beet at Giza region. J. Agric. Sci., Mansoura Univ., 13 (4): 1843-1946.

Guirguis, G. Z. (1985): Studies on certain insects attacking sugar beet in Western Desert, Egypt. Ph. D. Thesis, Fac. Agric., Menoufia Univ. 105 pp.

Iskander, A. K. (1982): Studies on certain sugar beet insects. M. Sc. Thesis, Fac. Agric., Cairo Univ.

Le Docte, A. (1927): Commercial determination of sugar in beet root using the socks. Sugar J., 29: 488-492.

Mousa, E. A. M. (2005): Studies on sugar beet main insects and their safety control methods. Ph. D. Thesis, Fac. Agric. Mansoura Univ.

Salouma, A. G. (1989): Biological and ecological studies on some insect pests of sugar beet and their natural enemies. Ph. D. Thesis, Fac. Agric. Alex. Univ., Egypt.

Sapronov, A. R.; Joshman, A. E. and Loseava, V. A. (1979): General technology of sugar and sugar substances. Phischevaya Promyshlennost Pub. Moscow, $464 \mathrm{p}$.

Youssef, A. E. (1994): Studies on certain insects attacking sugar beet. Ph. D. Thesis, Fac. Agric. Kafr El-Sheikh, Tanta Univ. 
El-Khouly M. I.

حساسية بعض أصناف بنجر السكر للإصابة بحشرتي ذبابة أوراق البنجر وخنفساء

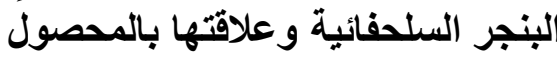

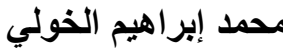
معهد بحوث وقياية النباتتاتـ مركز البحوث الزراعية ـ الدقي - جيزة - مصر

تم دراسة تذبذبات تعداد حشرتي ذبابة أور اق البنجر وخنفساء البنجر السلحفائية علي سبعة أصناف من بنجر السكر وهي ( (Lola, Carola, Kws 1436 , Hend9422, 3S وجد أن حشرة ذبابة أوراق البنجر لها من قمتين الي ثلاثة قمم في الموسم علي الأصناف المختلفة بينما حشرة

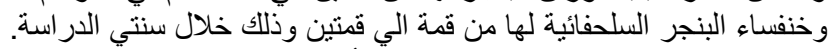

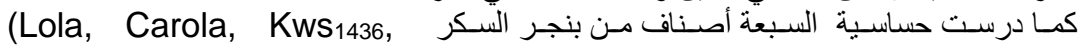
للإصـابة بحشرتي ذبابة أوراق البنجر وخنفساء البنجر Hend9422, 3S40, Anema and Top) السلحفائية.

حيث وجد أن الصنف Kws1436 كان أكثر حساسية من الصنف Top للإصـابة بذبابة أوراق البنجر في حين كان الصنف Hend9422 متوسط الإصابة بينما كان أكثر الأصناف حساسية لهذه الذبابة كان النية علي الجانب الآخر كـان الصنف Anema أكثر الأصناف حساسية للإصـابة بخنفسـاء البنجر

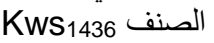

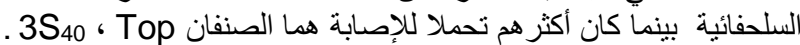

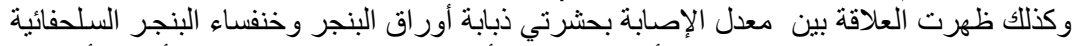

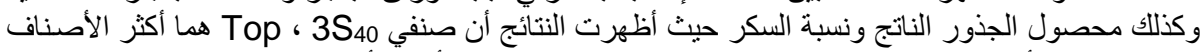

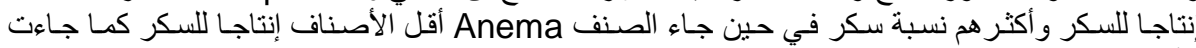
الأصناف الآخري في الوسط بينهما من حيث كمية السكر المستخرجة ونسين الكيتها.

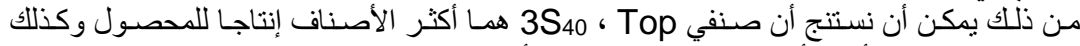

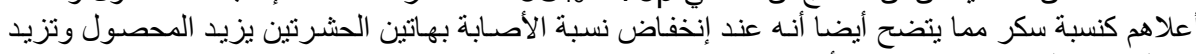
تبعا له نسبة السكر مقارنة بيقية الأصناف. وفي النهاية نقترح التوسع في زراعة الصنافنف 3S40 جنبا الي جنب الي الصنف Top لتفوقه علي بقية الأصناف ألمختبرة كما ونوعا. 